\title{
Critical Challenges to Protecting Unaccompanied and Separated Foreign Children in the Western Cape: LESSONS LEARNED AT THE UNIVERSITY OF Cape Town Refugee Rights Unit
}

\author{
TAL SCHREIER
}

\begin{abstract}
Despite South Africa having a relatively well developed legal and policy framework for securing the rights of children, there are a number of critical protection gaps that exist in terms of the implementation of these frameworks for unaccompanied or separated foreign children by magistrates, social workers and Department of Home Affairs' officials in particular. This report focuses on the key challenges that the UCT Refugee Rights Unit has experienced in the protection of unaccompanied foreign children in the Western Cape province. In addition to setting out the legal and policy frameworks for dealing with foreign children in South Africa, the paper reviews some of the Unit's cases and highlights various challenges in the course of undertaking this work. The key protection gaps that are highlighted include difficulties with or lack of suitable entry by foreign unaccompanied or separated children into South Africa's child care and protection system, the unclear interface between the refugee regime and the child protection regime, inability to access legal documentation, and the poor level of knowledge of the legal and protection frameworks by government and frontline service providers
\end{abstract}

\section{Résumé}

Bien que l'Afrique du Sud ait une structure juridique et politique bien développée pouvant protéger les droits des enfants, il existe un certain nombre de failles critiques dans l'application des lois et des politiques de protection concernant les enfants étrangers non-accompagnés ou séparés de leur famille, et ce entre autre par les magistrats, les travailleurs sociaux et les agents du Département des Affaires Intérieures. Ce rapport se concentre sur les défis centraux auxquels sont confrontés l'Unité des Droits des Réfugiés de la University of Cape Town dans leur travail de protection des enfants étrangers non-accompagnés de la province de Western Cape. En plus de mettre en lumière les lois et les politiques portant sur cette protection, cet article présente des cas particuliers traités par l'Unité, et les défis auxquels elle a été confrontée pendant cette étude. Les failles principales soulevées ici consistent en la difficulté ou le manque d'accès des enfants étrangers non-accompagnés ou séparés de leur famille aux services de santé et de protection des enfants, l'articulation confuse entre le régime des réfugiés et celui de la protection des enfants, l'impossibilité d'accéder à la documentation légale, et le niveau déficient de connaissance des lois et des politiques de protection par les gouvernements et les services de première ligne.

\section{Introduction}

Background and Research Objectives

Increasingly, children from countries as far afield as Somalia, the Democratic Republic of Congo and Zimbabwe are migrating and crossing South Africa's borders without 
their parents, relatives or care-givers. Some are abandoned by their care-givers or family members once in South Africa. Commonly referred to as unaccompanied minors, such children leave their home countries for a variety of reasons, including war and conflict, forced recruitment as child soldiers, harmful cultural practices, natural disasters and severe poverty. Some children are brought to South Africa by their parents or other adults for education or work opportunities and then left there, while some may be smuggled into the country clandestinely or brought by agents using false travel documents.

Children and adolescents represent the majority of migrants in Africa. ${ }^{1}$ Unaccompanied children are some of the most vulnerable migrants and require special protection appropriate for their situation. Irrespective of their reasons for migrating or the means in which they arrive in South Africa, they are particularly vulnerable to violence and exploitation as a result of not having any social or economic protection from caregivers, and also due to their means of travel and stay, which often result in their existence outside the scope of national law enforcement. ${ }^{2}$

Despite South Africa having a relatively well developed legal and policy framework for securing the rights of children, there are a number of critical child protection gaps that exist in terms of the implementation of these frameworks for unaccompanied or separated foreign children by Magistrates, Social Workers and Department of Home Affairs' ${ }^{3}$ officials in particular.

The Refugee Rights Unit (RRU) at the University of Cape Town has been providing free legal assistance to refugees ${ }^{4}$ throughout Cape Town since 1998. The RRU has as its principal objective the facilitation of local integration of refugees through its rights-based programme of legal assistance, which is founded upon international refugee and human rights law and South Africa's Constitution ${ }^{5}$ and Refugees Act. ${ }^{6}$ The RRU represents a number of unaccompanied and separated foreign children in the Department of Home Affairs asylum application process and within Children's Court inquiries, ${ }^{7}$ with the paramount principles of nonrefoulement and the best interests of the child guiding its activities. In addition to its direct legal services work, the RRU has been involved in formulating protocols for dealing with foreign unaccompanied children in the Western Cape. ${ }^{8}$

This paper will focus on the key challenges that the RRU has experienced in the protection of unaccompanied foreign children in the Western Cape, including lack of suitable entry into South Africa's child care and protection system, the unclear interface between the refugee regime and the child protection regime, inability to access legal documentation for this category of children, and the poor level of knowledge of the legal and protection frameworks by government and frontline service providers. This paper will draw upon a considerable amount of research that has already been done on the legal framework and treatment of unaccompanied foreign children in South Africa. However, where other works have focused on the experiences of migrant children in the country's border regions, in particular the large numbers of older Zimbabwean children in the northern region of South Africa, ${ }^{9}$ this paper will highlight the experiences of the RRU, the largest pro-bono legal services provider for refugees in Cape Town, which has a relatively smaller caseload of these matters primarily due to its geographic location, being far removed from South Africa's land borders.

In reviewing some of the recent children's matters that the RRU has been involved in, this paper will begin to explore to what extent the Western Cape province, which has been cited as the place where the acceptance of refugee children into the Children's Courts 'has been substantially higher than in the other eight provinces, ${ }^{\prime} 10$ is meeting the needs of unaccompanied foreign children in a meaningful manner.

\section{ii. Structure of Paper}

Part I of this paper will cover the current legal and policy framework for dealing with unaccompanied or separated foreign children in South Africa. It will include a brief review of the existing international, regional and domestic legislation and government policy documents pertaining to the treatment of these children, all of which demand their protection within South Africa. Lastly, it will include a review of the limited domestic case law on this topic. Part II will review the current state of protection of unaccompanied foreign children in South Africa. In particular, it will review some of the critical challenges in the child protection area in general and the particular vulnerabilities of foreign unaccompanied children, who may even demand a higher level of protection. This part will include the experiences of the RRU in its refugee and child protection activities via a review of cases in order to highlight the key challenges. Lastly, Part III of the paper will make conclusions on whether the protection needs of unaccompanied foreign children in the Western Cape are being met and offer some recommendations for the stakeholders for the way forward.

\section{International and Domestic Legal and Policy Frameworks for the Protection of Unaccompanied Foreign Children in South Africa}

Introduction

The protection of foreign unaccompanied children in South Africa is prescribed by both international and South African 
law. The legislative and policy framework for the protection of unaccompanied foreign children in South Africa is quite extensive. Not only has South Africa signed and ratified many international treaties pertaining to their rights, its domestic legislation concerning children is intended to extend to all children in the country. This section will review in brief some of the key pieces of the legislative and policy framework applicable in securing the rights of foreign unaccompanied children in South Africa. As a number of unaccompanied foreign children may be refugees ${ }^{11}$, the frameworks include the international and regional treaties pertaining to refugee protection.

An unaccompanied child is defined as "any person under 18 years of age who is separated from both parents and is not being cared for by an adult who by law or custom has responsibility to do so."12 Unaccompanied refugee children have specific needs and rights as refugees and also similar needs for care, education and special consideration as other children. Unaccompanied foreign children, whether documented or not, who do not qualify for refugee status also have extensive child protection rights. Both of these categories of children, like South African children, are entitled to protection under national child protection laws and international laws and standards such as the UN Convention on the Rights of the Child ${ }^{13}$ (UNCRC) and the African Charter on the Rights and Welfare of the Child ${ }^{14}$ (ACRWC). The rights as outlined in these Conventions constitute the consensus of the international community and should not come second place to South Africa's asylum and immigration policies.

\section{International and Regional Framework}

The UNCRC is the most comprehensive international treaty pertaining to children. It confirms that all children should be given equal status regardless of their nationality and that all children must be protected from harm and from discrimination. ${ }^{15}$ In terms of migrant children, the UNCRC requires states to take appropriate action to ensure that a child who seeks asylum or is considered a refugee receives protection and humanitarian assistance. ${ }^{16}$ It also requires family tracing and family reunification whenever possible. Where a family cannot be traced, the child is then deemed protected by the receiving country and is entitled to the same rights as any child in that country. ${ }^{17}$

Similar to the UNCRC, the 1999 ACRWC comprehensively sets out the rights of children with an emphasis on universal norms and principles for the status and protection of children, with non-discrimination and the "best interests" of the child being paramount. ${ }^{18}$ It also reinforces the rights of migrant children, in its "non-discrimination principle" in which it guarantees the rights of a child irrespective of the child's or his/her parents' or legal guardian's "race, ethnic group, colour, sex, language, religion, political or other opinion, national and social origin, fortune, birth or other status." 19

The ACRWC further provides that for a child seeking refugee status, the contracting state must cooperate with international organizations providing family tracing and reunification services, and if family reunification is not possible, the child should be accorded the "same protection as any other child permanently or temporarily deprived of his family environment for any reason." 20

In addition to clearly providing that all states must prohibit and prevent the sexual exploitation ${ }^{21}$ and trafficking ${ }^{22}$ of children, the ACRWC most significantly refers to the special protection required in order to secure the rights of unaccompanied, undocumented foreign children. In this regard, Article 25 of the ACRWC states that:

1. Any child who is permanently or temporarily deprived of his family environment for any reason shall be entitled to special protection and assistance;

2. States Parties to the present Charter:

(a) shall ensure that a child who is parentless, or who is temporarily or permanently deprived of his or her family environment, or who in his or her best interest cannot be brought up or allowed to remain in that environment shall be provided with alternative family care, which could include, among others, foster placement, or placement in suitable institutions for the care of children;

(b) shall take all necessary measures to trace and re-unite children with parents or relatives where separation is caused by internal and external displacement arising from armed conflicts or natural disasters.

3. When considering alternative family care of the child and the best interests of the child, due regard shall be paid to the desirability of continuity in a child's upbringing and to the child's ethnic, religious or linguistic background. ${ }^{23}$

The 1951 UN Convention Relating to the Status of Refugees $^{24}$ (hereinafter the "Refugee Convention") is the guiding international treaty that sets outs the rights of persons applying for refugee status and the responsibilities of signatory countries that grant asylum. While the Refugee Convention does not specifically mention the rights of children, many of its Articles and principles bear significance on children. Principally, the unanimously adopted recommendation in the Preamble to the Refugee Convention on the Principle of Unity of the Family recognizes the family 
as the "natural and fundamental group unit of society" and emphasizes that the essential right of a refugee to a family is constantly being threatened. This principle supports the view that states are required to take the necessary measures to protect the family unit by "protecting refugees who are minors, especially unaccompanied minors and girls with special reference to guardianship and adoption." ${ }^{25}$ Furthermore, Article 3 of the Refugee Convention stipulates that the provisions of the Convention should be applied without discrimination, which should be read to include discrimination on the basis of age. The fundamental principle of non-refoulement (non-return) therefore should apply to refugee children in the same manner as it would apply to adults. This principle provides that a refugee may not be returned to a place where his or her life is threatened due to race, religion, nationality, political opinion, or membership of a particular social group. ${ }^{26}$

The 1969 Organization of African Unity Convention Governing Specific Aspects of Refugee Problems in Africa ${ }^{27}$ (hereinafter the "OAU Convention") is the regional treaty on the rights of refugees and obligations of African State parties. Like the 1951 Refugee Convention, the OAU Convention does not contain specific rights for children. However, it does include a broader refugee definition, which is significant in terms of helping to assess whether a foreign unaccompanied child would qualify for refugee status in South Africa. The OAU refugee definition offers special protection to individuals, and therefore also unaccompanied foreign children, who have fled from their home countries due to war, civil disturbances and general unrest and violence. $^{28}$

\section{Domestic Legislative Framework}

In South Africa, domestic legislation provides significant protection for foreign unaccompanied children, largely in accordance with international norms. The principal legislation in this respect consists of the Constitution of the Republic of South Africa ("the Constitution"), ${ }^{29}$ the Children's Act ${ }^{30}$ and the Refugees Act. ${ }^{31}$ The Constitution provides refugees and asylum seekers with the most direct access to securing their rights. Most of the rights set out in the Constitution are not exclusively applicable to South African citizens; rather they extend to all foreign nationals living within its borders ${ }^{32}$ including foreign unaccompanied children.

Section 28 of the Constitution sets out the rights of all children in South Africa, including the "right to family or parental care or to appropriate alternative care when removed from the family environment," 33 the right to "basic nutrition, shelter, basic health services and social services," 34 and the right to "be protected from maltreatment, neglect, abuse or degradation." 35 The Constitution also provides that "a child's best interests are of paramount importance in every matter concerning the child." 36

South Africa's Children's Act ${ }^{37}$ of 2005 gives effect to the constitutional rights of children as set out in section 28 of the Bill of Rights ${ }^{38}$ and is the primary source of protection for all children in South Africa, irrespective of their origin, status or nationality. Unfortunately, the Children's Act does not specifically make any reference to foreign or refugee children, and the effect of this omission is that it arguably leads to a more exclusionary interpretation of the Act, causing many foreign children to fall through the cracks rather than squarely within the robust child protection regime in South Africa.

The South African Refugees Act of $1998^{39}$ reflects many of the standards of protection set out by the 1951 Refugee Convention and the OAU Convention. In terms of rights of unaccompanied children, the Refugees Amendment Act of $2008^{40}$ at section $21(\mathrm{~A})$ states as follows:

21(A)(1) Any unaccompanied child who is found under circumstances that clearly indicate that he or she is an asylum seeker and a child in need of care contemplated in the Children's Act, 2005 (Act No. 38 of 2005), must-

(a) be issued with an asylum seeker permit in terms of section 22; and

(b) in the prescribed manner, be brought before the Children's Court in the district in which he or she was found, to be dealt with in terms of the Children's Act, 2005. ${ }^{41}$

Unfortunately, to date, the 2008 Refugees Amendment Act has not yet come into force, as the required regulations that would give effect to the Act still have to be promulgated by the Minister of Home Affairs. The lack of regulations, or clear legislative guidance on this issue, perpetuates the critical protection gap in terms of the proper treatment of unaccompanied foreign children in South Africa. In July 2011, the Chief Director of Asylum Management in the Department of Home Affairs directly requested that civil society members provide input regarding procedures for dealing with unaccompanied foreign children. In particular how to define an unaccompanied foreign child, whether there are categories of unaccompanied children, and what would a proper referral system entail between the Department of Home Affairs and the Department of Social Development ${ }^{42}$ once an unaccompanied foreign child was identified.

In response to the above request, the UCT RRU made submissions on how the particular regulation that will 
give meaning to section 21A of the Amended Refugees Act should be drafted. The UCT RRU observed that any proposed regulation must "clearly delineate the role of the Department of Home Affairs, the Department of Social Development and the Children's Court ... in order to ensure that unaccompanied foreign children are properly dealt with and not left unattended, with lack of access to the services that they require and possibly at risk of being exploited or detained." 43

In its submission, the RRU highlighted a number of other critical issues, including the need for Home Affairs to put into place mechanisms to be able to properly identify separated children, ${ }^{44}$ the need to set up a referral system between the Departments of Home Affairs and Social Development, which should invariably include a mechanism for the recording of each child referred and which must be done without delay, and that a Children's Court inquiry, as contemplated in the Children's Act, should be opened for every unaccompanied foreign child. The RRU emphasized that it is the responsibility of the Children's Court, rather than the social worker alone, to make the necessary determination of whether a child is unaccompanied and in need of care and protection. As such, the Court should also be assisted by a legal opinion from an expert refugee lawyer, to determine whether the child appears to have a refugee claim. If so, then the Court should order that the child be documented as an asylum seeker and then a child-sensitive refugee status determination hearing can take place.

\section{Relevant Case Law}

The South African courts have made some significant pronouncements on the rights of unaccompanied foreign children in South Africa, thus in theory removing any doubt of the position of these children within South Africa's borders. In the 2005 case of The Centre for Child Law v Minister of Home Affairs \& Others, 45 the High Court of South Africa held that South Africa has a direct responsibility to care and protect unaccompanied foreign children. The case dealt with several unaccompanied foreign children being detained for lengthy periods of time in Lindela, ${ }^{46}$ accommodated together with adults, and who stood to be deported to their country by truck. On the recommendation of the curator ad litem, ${ }^{47}$ who was appointed on behalf of children, the children were transferred to a place of safety pending finalization of their Children's Courts inquiries, but the social workers assigned failed to conduct any further investigations into the children's circumstances.

The Court held that the government officials' behaviour constituted a serious infringement of the children's fundamental rights and that the government's failure to act in the best interests of the children was shameful. ${ }^{48}$ It further stated that a crisis existed in the handling of unaccompanied foreign children in South Africa; that such children were treated in a horrifying manner; exacerbated by an insufficiency of resources, inadequate administrative systems and procedural oversights. ${ }^{49}$ The Court was abundantly clear that all unaccompanied foreign children found in need of care should be dealt with in accordance with the provisions of the law, ${ }^{50}$ including asylum seeker and refugee children, meaning that these children must be brought before a Children's Court for an inquiry. ${ }^{51}$

In 2009, the Aids Law Project ${ }^{52}$ made an application to the High Court to appoint a curator ad litem for 56 named foreign children and any others that would be identified, many of whom were unaccompanied or separated from their care-givers, who were staying at the Central Methodist Church in Johannesburg. The Curatrix provided the court with a comprehensive report outlining her findings into the conditions of the unaccompanied children and her recommendations for the protection of these children. She confirmed that "there needs to be a more effective system for unaccompanied children as they enter the country" 53 and she strongly called for the "full implementation of the standard operating procedures for the identification, documentation, tracing and reunification of children." 54

In the most recent case of Shaafi Daahir Abdulahi and others v. Minister of Home Affairs and others ${ }^{55}$ in the High Court, the Department of Home Affairs' Refugee Reception Office refused to allow a seventeen year old unaccompanied foreign Somali child to apply on his own for asylum in the absence of a parent or guardian or a Children's Court order. $^{56}$ This was after a social worker had undertaken a home visit to the room that the child shared with some other unaccompanied Somali youth, and came to the conclusion that the child was not in a vulnerable position and decided not to open a Children's Court inquiry as he did not believe that the child qualified as a child in need of care and protection. ${ }^{57}$ In the urgent interim application, however, the High Court ordered that the child be documented by the Refugee Reception Office with an asylum seeker permit, pending the finalization of the matter. ${ }^{58}$ This case demonstrates an unfortunate misunderstanding that officials may have about foreign unaccompanied or separated children, in this case an older foreign child, who although may be able to care for himself, perhaps even find some informal work, is still extremely vulnerable without any documentation $^{59}$ legalizing his or her stay in the country.

To conclude, there are a range of legal provisions and precedents available to apply to the protection of unaccompanied or separated foreign children, and South Africa's domestic law provides for comprehensive legal protections for this vulnerable group. Regrettably, the challenges to the 
realisation of unaccompanied foreign children's rights lie in the implementation of the norms and standards enshrined in the law. This is particularly so where there are challenges to the child protection system as a whole in South Africa, in particular with regard to the resourcing of the system itself.

\section{Domestic Policy Framework}

Although South Africa has signed and ratified a number of significant international and regional treaties and has an extensive domestic legislative framework in place to protect unaccompanied or separated foreign children, the approach on the ground is far from ideal. This is mainly due to the lack of knowledge and understanding of the legislative provisions by the key stakeholders meant to protect vulnerable unaccompanied foreign children. While policy development for the management of unaccompanied foreign children has been progressing over the past several years, ${ }^{60}$ the new national Department of Social Development Guidelines on Separated and Unaccompanied Children Outside their Country of Origin in South Africa (hereinafter the "DSD Guidelines") only surfaced ${ }^{61}$ in 2011.

As background, in 2007/8, the UCT RRU developed standard operating procedures for dealing with unaccompanied foreign children, for all stakeholders in the Western Cape. ${ }^{62}$ That same year the UCT RRU, in conjunction with the Department of Social Development, ${ }^{63}$ the UNHCR, ${ }^{64}$ and the South African Red Cross Society, ${ }^{65}$ trained over 150 social workers from throughout the Western Cape on these standard operating procedures. Remarkably, at that time, the only publicly available government policy document on unaccompanied foreign children ${ }^{66}$ not only incorrectly referred to them as "illegal" and thus outside the national child protection system, but also provided merely superficial guidance ${ }^{67}$ to relevant officials on what to do if they encounter such a child.

More recently, however, the National Social Development Children's Act Practice Note No. 2 of $2011,{ }^{68}$ clearly confirms that the Children's Act defines a child as any person under the age 18; that "all foreign children whether documented or not who are reported to be in need of care and protection must be treated or assisted like South African children;" and, that "all the provisions of the Children's Act apply to foreign children." 69

The 2011 DSD Guidelines refer in detail to the international and domestic legal standards that must be met for the protection of unaccompanied or separated foreign children. ${ }^{70}$ It further sets out detailed, however not exhaustive, steps to follow when assisting such children, from identification stage to assessment and documentation stage, through to temporary safe care and then finally to formal placement and options for durable solutions. ${ }^{71}$ Aside from these new but not readily available DSD Guidelines, currently there is no other official document in the public domain on foreign unaccompanied or separated children in South Africa.

In conclusion, a policy framework in South Africa finally exists in support of the rights of unaccompanied or separated foreign children, regardless of their documentation or status. It is the wide gap between this new framework and its application or implementation by the relevant government officials that is the most critical challenge to the effective protection of this extremely vulnerable group of migrants. The next section of this paper will focus on the various manifestations of this challenge, as highlighted in cases in which the UCT RRU appeared on behalf of unaccompanied or separated foreign children both within the Department of Home Affairs asylum process and before the Children's Court.

\section{Challenges to Effective Protection}

The UCT RRU has provided legal representation to unaccompanied or separated refugee children for the past decade. The key protection gaps that have been identified by the Unit include the lack of suitable entry pathways into South Africa's child care and protection system, the unclear interface between the refugee regime and the child protection regime, the lack of access to legal documentation, and the poor level of knowledge of the legal and protection frameworks by government and frontline service providers. This section of the paper will review some of the RRU's cases and highlight various experiences of the RRU in the course of undertaking this work.

\section{Entry into the Child Protection Regime}

The court cases discussed in Part I of this paper were brought by civil society members on behalf of foreign unaccompanied or separated children who were not able to suitably access the child protection system of South Africa. The lack of sufficient knowledge by social workers and magistrates ${ }^{72}$ of the legal framework and procedures pertaining to unaccompanied foreign children contributes directly to this problem. In addition, the confusion amongst Department of Home Affairs' officials, social workers and magistrates regarding the interface between the refugee regime and the child protection system is another factor. Lastly, the attitudinal barriers of some government officials must be factored in, as it is difficult to understand why vulnerable children's rights are simply ignored on the basis that they are not South African. ${ }^{73}$ These interconnected issues, which ultimately result in foreign children not being able to access the child protection regime in South Africa, will be dealt with together in this section. 
It should be noted upfront that difficulties in identifying unaccompanied foreign children in South Africa's urban areas means that these children are excluded from the national care and protection systems. The DSD Guidelines confirm that "due to their particular circumstances, in some cases separated and unaccompanied children may be fearful or distrustful of authorities ... [and] this makes them extremely hard to reach by the police and social workers." 74

The DSD Guidelines, at Section 6.1 specifically state that "unaccompanied [foreign] children should be assumed to be children 'in need of care and protection' 75 and may be placed in temporary safe care." 76 Despite this clear statement, the UCT RRU has observed numerous blockages or refusals by social workers to open up Children's Court inquiries on behalf of foreign unaccompanied or separated children. As was the case in the Shaafi matter, the refusal to approach the Children's Court often results from the conflict or what the UCT RRU refers to as 'the stand-off' between the refugee regime and the child protection regime, whereby the Department of Home Affairs refuses to assist the unaccompanied foreign child without a Children's Court order, and the social worker refuses to open up a Children's Court inquiry as he or she does not feel that the child in question is "in need of care and protection." 77

In the following UCT RRU case, the matter did not even reach the purview of the Children's Court. This case involved a 15 year old orphaned Burundian child who travelled alone to South Africa in 2010 in search of his cousin, ended up in Durban where he met the cousin's sister, and subsequently moved to Cape Town to join his cousin. The UCT RRU referred the child to a social worker on or about August 2011 as the Department of Home Affairs' Cape Town Refugee Reception Office refused to extend the child's asylum seeker permit. ${ }^{78}$ Upon request of the UCT attorney, the social worker conducted a home visit and thereafter prepared a report, addressing the guardianship issue and concluding that the boy's cousin "is capable to care for the child concerned; therefore he can remain the guardian and primary care giver to the child concerned."79 This report was provided by the UCT attorney to the Cape Town Refugee Reception Office, who refused to accept it as the basis for extending the child's asylum seeker permit, stating that they required a formal Children's Court order in order to do so. ${ }^{80}$ When the UCT attorney conveyed this feedback to the social worker, the social worker provided a lengthy written response, which included the following reasons why she could not further assist:

If a Court Order is required, it means that I must open a Children's Court Inquiry in order to get a Temporary Safe Care Order, placing the child in temporary care of Jonathan. To place a child in someone's Safe Care is not easy. I refer to the Children's Act where the Safety Parent has to undergo a full screening to determine his suitability to care for a child as well as a Police Clearance Certificate. His name has to be cleared on the Child Protection Register!

If in his case, the parents are deceased, I need death certificates for both parents. If no one can give me a death certificate, I have to refer the matter to International Social Services that needs to make contact with someone in his country to obtain these certificates. That is a process that can take 6 months to one year.

Once Court is opened, I am responsible to finalise the matter within 90 days. Finalising entails an in-depth investigation into the caregiver's circumstances and suitability. The child concerned's wellbeing must be investigated in-depth. The caregiver must go through extensive training at this office. I also query the possibility to place the child in foster care with Jonathan if he is only an Asylum Seeker.

After speaking about this case in length with Department of Social Development it appears that at this stage, getting a Court Order is not the best route to follow.

According to the Dept. official, she agrees with above information and is of opinion that if I do not follow the correct procedure once Court is opened, I place myself in a position that can bring me in a lot of trouble.

To get a Court Order for the purpose of the minor getting an extension of his Asylum Seeker paper is not a reason to open Court. The Dept. official queries the fact that this boy has a Permit-based on what reasons was this Permit initially issued? Why now does he need a Court Order? I recommend that you go back to Home Affairs with my report and negotiate with them to issue the permit based on my report. Previously I had a similar case, and Home Affairs issued a permit to a young boy based on my report. ${ }^{81}$

While the social worker in this case demonstrated that she had a good grasp of the issues involved, her comments provide insight into the critical state of affairs that has resulted from lack of detailed regulations pertaining to the Amended Refugees Act, as described in the legal framework section above, and/or lack of specific operational guidelines for government officials on how to deal with unaccompanied or separated foreign children seeking asylum. Without any directives on point, the Department of Home Affairs Cape Town Refugee Reception Office is loath to document (or extend a permit) for a child not in the care of their parents, without a Children's Court order, and thus continues 
to refer matters to the Department of Social Development for a Children's Court order.

The UCT RRU and the author assert that a social worker may not, as in the above case, unilaterally refuse to refer a matter to the Children's Court as it is for the magistrate of the Children's Court to determine-with the assistance of a social worker's report and other investigations-a child's circumstances i.e. whether the child is in need of care and protection, whether or not to place the child in a place of safety, or to whom to assign care of the child.

The DSD Guidelines provide sufficient guidance on the initial assessment phase that a social worker must undertake when a child is identified as separated or unaccompanied. In this regard, the Guidelines state the following:

Children who are identified as separated or unaccompanied should be referred to a social worker or police official. Unaccompanied children should be assumed to be children 'in need of care and protection' and may be placed in temporary safe care. If the current care circumstances of separated children do not put them at immediate risk, separated children may be assessed by a social worker without being placed in temporary safe place. However if the separated child appears to be a victim of an exploitative or abusive relationship, he or she should immediately be placed in temporary safe care. ${ }^{82}$

The above directives suggest that once a child is referred to a social worker, investigations by the social worker are to take place (i.e. an obligation exists) in order to determine if the child is in need of care or protection. In this regard, Regulation 54 of the Children's Act $^{83}$ is significant, in that it squarely addresses the situation where an investigation by the social worker is pending or underway. The regulation instructs that the matter, even though it is only under investigation, must be brought before the court for a determination. ${ }^{84}$

Furthermore, it is argued that in situations where the court ends up determining that a child is not in need of care or protection, the court may in terms of its powers set out in Section $46^{85}$ read together with Section 23 of the Children's Act, order that care of the concerned child be granted to any person having an interest in the care, well-being or development of the child, taking into consideration the best interests of the child, the relationship between the child and the applicant, and any other factor. ${ }^{86}$

The above case clearly brings to the fore one of the key areas of concern of the UCT RRU of unaccompanied foreign children not readily being able to enter the child protection system, due to government officials' blockages and/ or a lack of understanding of the legal frameworks, procedures and ultimately the rights of this vulnerable category of migrants. The most worrying result is that simply leaving a child to be undocumented can lead to numerous problems, such as the unlawful discontinued enrolment in school and lack of proper access to basic services like emergency or health care services.

Another disturbing case that recently came to the attention of the UCT RRU and that highlights the issue of officials' dire lack of knowledge of the framework pertaining to foreign children, was that of a Children's Court Commissioner in Mossel Bay ${ }^{87}$ who refused to acknowledge the rights of an abandoned foreign child. In this matter, a social worker from the DSD district office in Mossel Bay contacted the author in July 2011 for advice about a case she was involved in. She explained that a Mozambican mother gave birth to a child in a local public hospital and abandoned the child, stating that she was going to go back to Mozambique with her two year old son. Upon advice of the author and on the social worker's conclusion that the abandoned child was in need of care and protection, a Children's Court Inquiry was opened. The magistrate requested that the social worker attempt to track down the father, whom the mother said was South African, but she did not know his whereabouts or his personal details. The magistrate refused to acknowledge that the infant child was South African as no clear evidence existed to prove this.

Unfortunately, despite the report of the social worker that the mother wanted nothing to do with the child and would abandon the child, the magistrate refused to find the child in need of care or protection and instructed the mother that she must take the child with her to Mozambique, going so far as to hand the mother and child over to immigration officials in order to effect a deportation. The social worker later learned that the mother in fact abandoned the infant shortly after re-entering her country of origin. The magistrate clearly decided unlawfully that the foreign child, abandoned in South Africa, was not entitled to care and protection within South Africa. The case demonstrates either a very ignorant magistrate as to the legal and procedural frameworks pertaining to foreign children in South Africa, or a particularly xenophobic one. The social worker on the other hand must be commended for having made efforts to properly inform herself of the legal entitlements of the child and the author understood that she also argued strongly for the care and protection of the infant child in this case. Certainly, the fact that this matter took place in a small town, far removed from the well-resourced Cape Town may have contributed to this unfortunate outcome, where no legal representation was provided to the mother or child and where there was no civil society organization that could have readily intervened. 
Even in Cape Town, where the UCT RRU have for many years been involved in refugee and migrant children matters in magistrates' courts, as well as working closely with numerous social workers of the Department of Social Development and where the actual numbers of such vulnerable children ${ }^{88}$ is relatively manageable, the obstacles as described above continue to persist.

In response to the aforementioned resistance that the UCT RRU has experienced from social workers in trying to open up Children's Court inquiries, one of the senior attorneys of the UCT RRU recently approached the court independently as an interested party ${ }^{89}$ to open up an inquiry on behalf of an orphaned 14 year old foreign child who left the Democratic Republic of Congo to join his older adult brother in Cape Town. The Department of Home Affairs' Refugee Reception Office had refused to provide the boy with an asylum seeker permit (even as a dependant of his brother) and the social worker refused to open up a Children's Court inquiry for him, as she determined that the boy was not in need of care or protection, since he was being well cared for by his older brother.

The UCT attorney accordingly approached the Children's Court with the brother of the boy, and under section 53 of the Children's Act, ${ }^{90}$ applied to the court to open up a Children's Court inquiry directly and without a social worker. The clerk of that court was initially resistant, but in the end allowed the attorney to proceed. At this time, however, the investigations into the matter are still pending. UCT argued in this case, that pursuant to Section 23 of the Children's Act, ${ }^{91}$ the court, in determining the best interests of the child, can assign the care for the child to an interested person-in this case the brother of the childby order of the court. Such an order would ensure that the undocumented foreign child who is being cared for by an extended member of the family, and who appears to have a refugee claim can be documented by the Department of Home Affairs either on his own as an asylum seeker or as a dependant of a refugee.

\section{Legal Documentation}

One of the most challenging aspects in the protection of foreign unaccompanied or separated children in South Africa is the issue of legal documentation. Where a child appears to have a refugee claim, it is more readily understood that the child should be documented as an asylum seeker at the Department of Home Affairs' Refugee Reception Office. As discussed above, at this time however, the major barrier to this is the refusal of the Department of Home Affairs to allow for the unaccompanied or separated child's application for asylum without a Children's Court order ${ }^{92}$, and the social workers' refusals to open up Children's Court inquiries. Interestingly, in the past, when seemingly less was understood by the relevant officials about the legal frameworks, almost all foreign children-irrespective of whether they had a genuine refugee claim or not-were documented as asylum seekers. In most of these cases, the Department of Home Affairs simply postponed or delayed the finalization of the asylum claims until the child turned 18, partly as a result of their confusion or lack of knowledge regarding how to deal with such cases. ${ }^{93}$

The most significant challenge with regard to legal documentation relates to unaccompanied foreign children who do not appear to have a genuine refugee claim. According to the UNHCR Guidelines on the Protection and Care of Refugee Children ${ }^{94}$, the best interest of an unaccompanied foreign child who has been denied refugee status (or who may not qualify for refugee status), requires that the child not be returned to his or her country of origin, unless, prior to the return: a parent has been located in the country of origin who can take care of the child and the parent is informed of all the details of the return; or, a relative, or other adult care-giver, government agency or child-care agency has agreed and is able to provide immediate protection and care for the child upon arrival. Accordingly, it would follow that if a foreign child cannot be returned to his or her country of origin, long term planning for the child needs to take place in South Africa. ${ }^{95}$

The UCT RRU advocates that a critical aspect of longterm planning for a foreign child who is not a refugee is the child's documentation needs. Unfortunately, as confirmed by UNICEF, in South Africa there is a serious "lack of accessible documentation for unaccompanied minors ... [as] at present there are limited options for documentation of unaccompanied minors according to the Children's Act, the Refugees Act and the Immigration Act." 96 The DSD Guidelines, in the Assessment and Documentation section, state that when any unaccompanied or separated foreign child is identified:

\footnotetext{
... the child should be immediately registered and documented. This process should be conducted in an age-appropriate and gender sensitive manner, in a language the child understands, by professionally qualified persons. Assessment and documentation should include the compilation of key personal data and further information in order to meet the specific needs of the child and to make a plan for his or her future, This information includes the identity and location of family members, the reasons for being separated or unaccompanied, and an assessment of particular vulnerabilities and protection needs. ${ }^{97}$
}

The above provisions, while indeed comprehensive, only provide social workers with guidance on the extent of 
information that should be recorded about the child, while failing to specifically indicate what type of document the child should have that could legalize their stay in South Africa, until all investigations including family tracing are finalized, and particularly if no reunification in the country of origin can take place. This is a serious oversight as often a child that does not have a refugee claim (and thus does not obtain an asylum seeker document or gets rejected within the asylum adjudication process) ends up for years having nothing but a copy of his or her Children's Court order as the only form of identification in South Africa. Not only does this violate a child's basic right to identification ${ }^{98}$, this leads the child to "experience challenges with taking matriculation exams, entering into sport competitions" 99 and could even make them vulnerable to labour exploitation.

This is an area that needs further advocacy in light of the fact that many foreign children in South Africa cannot easily be reunified with their families in their country of origin, and/or the safe return to the country of origin cannot take place due to lack of secure of concrete arrangements for care and custodial responsibilities in the country of origin. ${ }^{100}$ This means that such children must be placed into formal long-term care in South Africa, and the UCT RRU asserts that these children must be provided with some form of proper legal documentation, enabling their stay in South Africa.

The above problem is certainly heightened when foreign children that have been placed in long term care in the South African child care system, but do not have any South African identification documents (or perhaps had an asylum seeker permit that was issued many years ago and never properly extended, and would in any event not qualify for refugee status), turn 18 and must be removed from the child care system. ${ }^{101}$ In such situations, the UCT RRU proposes that a possible option is to apply to the Minister of Home Affairs in terms of section 31(2)(b) of the Immigration Act $^{102}$ for a Ministerial Exemption. ${ }^{103}$ The Curatrix in the Aids Law Project case recommended the same approach in her report. More specifically, that:

... under [section 31(2)(b) of the Immigration Act] , the Department of Home Affairs would be able to make provision for a system where unaccompanied children are documented and provided with legal papers. The essential aspect for children is that they would not be stateless and could be granted some of the rights that permanent residents acquire, in particular those that will assist them to enjoy the protection that the Constitution affords to children. While the Children's Court procedure is generally the best way to deal with unaccompanied children, it may not be suitable for children who are already 17 years of close to turning 18 years old. Once they attain 18 years, they are no longer children and they will be out of the care system and undocumented. It would be unwise to let these young people wander within the Republic without any documentation. ${ }^{104}$

It remains to be seen how such an exemption application to the Minister would be received, as to date, the UCT RRU has not had response from the Minister in any of its current exemption application cases. There does exist a clear precedent, however, in terms of the Minister's use of this exemption mechanism to grant temporary or permanent residence to other migrants on humanitarian and compassionate grounds. ${ }^{105}$

\section{Conclusions}

This paper has demonstrated that while the policy and legal frameworks to protect the basic rights of foreign unaccompanied or separated children are in place in South Africa, it is in the implementation of these rights that there is often a denial of services to or confusion about the rights of different categories of migrant children. This report has further attempted to describe the situation in and around Cape Town having distinguished this region from the borders and rural areas of South Africa. Despite the fact that Cape Town is relatively well-resourced in terms of the number of NGOs servicing refugees and migrant children, the challenges that exist in this area, as evidenced by the above case studies from the UCT RRU, provide a bleak picture of these children's rights continuing to be violated, in particular in the areas further afield from Cape Town.

It is acknowledged that South Africa experiences what is referred to as a mixed flow of migrants, which can be defined as a combination of different categories of migrants arriving into South Africa, each with different incentives and motivations for their migrations and each with varying levels of vulnerability. In this context, unaccompanied foreign children represent one of the most vulnerable categories of migrants, and "active identification and referral of unaccompanied children is often necessary ... in order to intercept children who are trafficked, exploited, or simply unaware of the possibility of seeking protection or assistance in the new country."106

It is crucial that the government of South Africa is aware of the particular issues covered in this report in particular the areas in which children's rights are being severely compromised or violated. While the new DSD Guidelines, i.e. the pronouncement of policy by the government of South Africa on unaccompanied or separated foreign children is welcome, in other ways the government is demonstrating that its main objective is to actually prevent migration at all costs into the country, rather than to focus on the protection needs of this vulnerable group. ${ }^{107}$ Certainly, the 
government of South Africa should address the prevention of unsafe migration, such as trafficking, and focus on addressing the root causes of migration. However, it must also strive to create an environment that would allow foreign children growing up in South Africa good prospects of personal development and decent standards of living.

The recent introduction of the DSD Guidelines, which impressively set out the best practice guidelines for dealing with unaccompanied and separated foreign children in South Africa is a significant step towards addressing many of the concerns raised in this paper; however the UCT RRU urges government to widely publicize and provide ongoing training to all relevant stakeholders on these important Guidelines. The UCT RRU further urges the Department of Home Affairs to gazette regulations, to operationalize the Refugees Amendment Act, and provide the much-needed legislative guidance to its officials on procedures to follow when dealing with unaccompanied and foreign children. Lastly, it goes without saying that extra resources should be allocated to government social workers in order to build their capacity to meaningfully apply the DSD Guidelines in favour of the foreign children that they are obligated to protect.

\section{Notes}

1. In Central Africa, in the Great Lakes region, and in the East and Horn of Africa regions, children and adolescents constitute 56 per cent of people of concern to UNHCR. In 2009 , more than 18,700 asylum applications were lodged by unaccompanied and separated children in 71 countries, constituting 4 per cent of all claims lodged in these countries. Data also indicated that it is often unaccompanied or separated boys who seek asylum, in particular in industrialized countries where about two-thirds of all unaccompanied and separated children are male, and that the number of those seeking asylum was on the rise as compared to only two or three years ago. In developing countries, however, the sex distribution was more balanced. Note: Since 2006, UNHCR has systematically collected data on unaccompanied and separated children claiming asylum including their age, sex and country of origin (the latter since 2007). Despite these efforts, the global number of unaccompanied and separated children who annually submit individual asylum claims remains unknown, largely because of the different registration mechanisms in place as well as the fact that certain countries, such as Canada, South Africa, and the United States of America, do not provide this information. See UNHCR Statistical Yearbook 2009, accessed on 31 October 2011 at http://www.unhcr. org/4ce532ff9.html

2. Liv Feijen, "The Challenges of Ensuring Protection to Unaccompanied and Separated Children in
Composite Flows in Europe," Refugee Survey Quarterly, UNHCR 2009 at 3, accessed on 31 October 2011 at http://rsq.oxfordjournals.org/content/27/4/63.full.pdf +html?sid=2dfc56b0-2206-40df-a119-eb48390b8d42.

3. The Department of Home Affairs is responsible for the adjudication of asylum claims and the issuance of refugee documentation to asylum seekers and recognized refugees.

4. The RRU provides legal assistance to refugees and asylum seekers, whether documented or undocumented. In South Africa, a refugee is someone who has been granted refugee status from the Department of Home Affairs (DHA) and an asylum seeker is someone who has lodged an application for asylum with the DHA which has not been finalized. For the purposes of this paper, the term refugee shall refer to refugees or asylum seekers (undocumented or not) who have approached the RRU for legal protection.

5. Act 108 of 1996.

6. Act 130 of 1998.

7. A Children's Court inquiry refers to a case brought before the Children's Court in terms of the South African Children's Act 38 of 2005, for example, when a social worker makes investigations into and reports to a Magistrate on whether a specific child is in need of care and protection.

8. This has provided the RRU with the opportunity to engage many key stakeholders and train social workers in the legal and policy frameworks pertaining to unaccompanied foreign children in South Africa. The training was undertaken in conjunction with key partners, such as the Department of Social Development, the International Organization for Migration, the UNHCR and the South African Red Cross Society. In 2008, the UCT RRU trained approximately 150 social workers and in 2011, 120 social workers, from throughout the Western Cape Province.

9. See for example Cerise Fritsch, "The plight of Zimbabwean unaccompanied refugee minors in South Africa: a call for comprehensive legislative action," Denver Journal of International Law and Policy (Fall, 2010), 38 Denv J Intl L \& Pol'y 623, available at http://findarticles.com/p/articles/ mi_hb3262/is_4_38/ai_n55121899/?tag=content;col1; or Save the Children UK, "Children crossing borders: Report on unaccompanied minors who have travelled to South Africa," (July 2007), accessed on 15 October 2011 at http:// www.savethechildren.org.uk/en/docs/children-crossing -borders.pdf; or Ingid Palmary, "For Better Implementation of Migrant Children's Rights in South Africa," (UNICEF 2009 Report), accessed on 15 October 2011 at http://www. unicef.org/southafrica/SAF_resources_migrantchild1.pdf, which draws mainly upon research conducted in Musina, Komatipoort and Johannesburg; or "Children Crossing Borders: Report on unaccompanied minor who have travelled to South Africa," (Save the Children UK 2007), accessed on 15 October 2011 at http://www.savethechildren.org.uk/en/docs/children-crossing-borders.pdf; and, CORMSA, "Report to the Government of the Republic of South Africa on the Humanitarian Crisis in Musina, 
South Africa, 23 February 2009, " accessed on 15 October 2011 at http://www.cormsa.org.za/wp-content/uploads/ Resources/Crisis_in_Musina.pdf.

10. Jeff Handmaker et al., Advancing Refugee Protection in South Africa (New York: Berghahn Books, 2008), 196.

11. This paper focuses on the experiences of mainly refugee children, as the mandate of the UCT RRU is to ensure protection for genuine refugees, and the author is drawing mainly on her experience within the refugee context. Although unaccompanied or separated refugee children may be arguably the most vulnerable, one cannot ignore that all migrant children are beneficiaries of special rights and should be protected because they are children.

12. United Nations High Commissioner for Refugees, "Refugee Children: Guidelines on Protection and Care 1994," accessed on 10 August 2011 at http://www.unhcr.org/refworld/docid/3ae6b3470.html, 121. An unaccompanied or separated child is not defined in South African law.

13. Convention on the Rights of the Child, 20 November 1989, 1577 U.N.T.S. 3, 28 I.L.M. 1456 (entered into force 2 September 1990), hereinafter the UNCRC.

14. African Charter on the Rights and Welfare of the Child, 11 July 1990, OAU (Doc. CAB/LEG/24.9/49, (entered into force 29 November 1999), hereinafter the ACRWC.

15. Art 12 of UNCRC.

16. Art 22(1) of UNCRC.

17. Art 22(2) of UNCRC.

18. Art 4 of ACRWC.

19. Art 3 of ACRWC.

20. Art 23(3) of ACRWC.

21. Art 27 of ACRWC.

22. Art 29 of ACRWC.

23. Art 25 of the ACRWC.

24. Convention Relating to the Status of Refugees, 189 U.N.T.S. 150, (entered into force 22 April 1954), hereinafter the Refugee Convention.

25. Palmary, "For Better Implementation," 9.

26. Art 33 of the Refugee Convention.

27. Convention Governing Specific Aspects of Refugee Problems in Africa, 1001U.N.T.S. 45, (entered into force 20 June 1974), hereinafter the OAU Convention.

28. Art 1(2) of the OAU Convention states "the term 'refugee' shall also apply to every person who, owing to external aggression, occupation, foreign domination or events seriously disturbing public order in either part or the whole of his country of origin or nationality, is compelled to leave his place of habitual residence in order to seek refuge in another place outside his country of origin or nationality."

29. Act 108 of 1996, hereinafter the Constitution.

30. Act 38 of 2005.

31. Act 130 of 1998.

32. In Lawyers for Human Rights and Another $v$ Minister of Home Affairs and Another ((2002 (8) BCLR 891 (T)), the court confirmed that the Bill of Rights of the Constitution applies to all persons except with express exceptions (at 897C-D).

33. Sec 28(1)(a) of the Constitution.

34. Sec 28(1)(b) of the Constitution.

35. Sec 28(1)(c) of the Constitution.

36. Sec 28(2) of the Constitution.

37. Children's Act No 38 of 2005.

38. Sec 7(1) of the Constitution confirms that the Bill of Rights is "the cornerstone of democracy in South Africa. It enshrines the rights of all people in our country and affirms the democratic values of human dignity, equality and freedom." Section 7(2) states that the "state must respect, protect, promote and fulfil the rights in the Bill of Rights."

39. Act 130 of 1998 .

40. Act 33 of 2008 .

41. Ibid., section 21(A). This amendment replaced the principal Act's section 32, which dealt with an unaccompanied child in terms of the previous Child Care Act, 74 of 1983.

42. The Department of Social Development is the national government department mandated with ensuring the protection and appropriate care of children in South Africa. Its social workers are the frontline service providers of the Department, who have the statutory authority to conduct investigations into the welfare of a child and open up a Children's Court inquiry.

43. Submission on file with the author.

44. So that where an adult accompanies a child, it will be necessary to establish the nature of the relationship between the child and the adult in order to establish whether or not the adult is in fact the child's primary caregiver. There is otherwise the risk that a trafficked or smuggled child may be documented as a dependant of an asylum applicant, when in fact there is no genuine relationship between the child and the adult. This would entail specially trained officials at each Refugee Reception Office to attempt to ensure than the true nature of a relationship between a child and the principal asylum applicant is confirmed, wherever children are involved and if necessary, the official can refer the child to DSD appropriately so that a Children's Court Inquiry can be opened.

45. The Centre for Child Law and Another v Minister of Home Affairs and Others, 2005 (6) SA 50 (T).

46. Lindela is the repatriation facility in Krugersdorp, South Africa, where illegal foreigners are detained while awaiting their deportations.

47. A lawyer appointed by the Court to represent the interests of the children.

48. Centre for Child Law, at par 31.

49. Ibid., at par 14.

50. Child Care Act No. 74 of 1983, which was replaced by the Children's Act of 2005.

51. Centre for Child Law, at par 20-22.

52. A South African non-governmental organization.

53. The Aids Law Project v. Minister of Social Development and Others South Gauteng High Court, unreported, (52895/09) 
Curatrix Ad Litem's Report filed 8 February 2010, at par 6.4.1-6.4.2.

54. Ibid. The Curatrix was referring to the, at the time still indevelopment Department of Social Development Guidelines, which are discussed in greater detail in the next section of this paper.

55. Shaafi Daahir Abdulahi and others v. Minister of Home Affairs and others, (26572/2011), North Gauteng High Court.

56. For placement in temporary safe care in terms of the Children's Act as a child in need of care or protection.

57. Ibid.

58. At the time of writing the report, the matter was sub judice.

59. as the Department of Home Affairs is refusing to allow such children to apply on their own for asylum, without a Children's Court order.

60. In 2009, the author of this report was invited to a meeting with the head of Child Protection for UNICEF South Africa, Mr Stephen Blight and the National DSD Chief Director International Social Services, Mr Tebogo Mabe to discuss the standard operation procedures for dealing with Unaccompanied Foreign Children that UCT developed in 2008 in the Western Cape. The South African government began working closely with UNICEF and Save the Children to develop its policy guidelines for foreign unaccompanied children from about this point onwards.

61. See below for a discussion of how difficult it is to find this document publicly; furthermore, of the 120 social workers that the author trained in late 2011 on the legal framework pertaining to unaccompanied foreign children in South Africa, not one was aware of this important policy document.

62. In consultation with relevant stakeholders including: UNHCR, DSD, ISS, Red Cross, DHA, a Children's Court Commissioner in Cape Town and partner NGOs following several meetings during 2006 and 2007 to identify protection gaps and determine mechanisms for enhancing protection of refugee and unaccompanied foreign children. Some of the key principles highlighted in the SOPs include that unaccompanied or separated foreign children found in South Africa should be assumed to be in need of care and protection; that there is a legal obligation to treat all foreign children in the same manner as South African children if they are at risk; that any person or entity can help identify and refer an unaccompanied foreign child to the DSD or Police; that DSD must open a Children's Court Inquiry for every foreign child who appears to be in need of care and protection as contemplated in the Act; that tracing or family reunification endeavours should begin as soon as possible after identifying an unaccompanied child; that legal representation for the child must be provided for, within the Children's Court process and if the child appears to have a refugee claim, within the asylum process.

63. With DSD provincial office Chief Social Worker Ms. Marie Louw, who was also the Provincial Coordinator for the
South African affiliated bureaux of the International Social Services.

64. The Senior Community Services Officer of the Southern Africa regional UNHCR office, based in Pretoria, Ms. Mmone Molestane.

65. The SARCS and the International Committee for the Red Cross are mandated to trace families across international borders.

66. The DHA Director General's 23 May 2002 letter entitled "Procedure in Respect of Unaccompanied Minor Illegal Aliens" and the DHA's Passport Control Instruction No 1 of 2004 entitled "Procedure in Response of Unaccompanied Minor Illegal Foreigners," both of which on file with the author.

67. For example, the one-page DHA letter states that after an immigration official reports a child to a social worker, " ... the social worker will be responsible for the Children's Court Inquiry although close collaboration will be important between the social worker and the immigration officer throughout the process." The (5-paragraph long) Passport Control Instruction does go a bit further to state that investigations into the child's circumstances in his or her country of origin must be made through the DSD in collaboration with International Social Services for 'responsible deportation/family reunification' to take place, and that a child must not be detained except as a measure of last resort.

68. Obtained by the author from a civil society partner, that also works with migrant children; copy of same on file with author.

69. Ibid.

70. Unfortunately, the Guidelines are to date still not readily accessible. In fact, they only became known to the author following a public statement made by the Deputy Minister of Social Development referring to them. A subsequent search online for the Guidelines was not successful, and it was not until a more concerted effort was made through the UCT RRU's stakeholder network, that a copy of the document was obtained.

71. Specific recommendations from these DSD Guidelines will be referred to in the evaluation section of this paper below.

72. Sec 42, Children's Act: "(1) For the purposes of this Act, every magistrate's court ... shall be a children's court and shall have jurisdiction on any matter arising from the application of this Act for the area of its jurisdiction. (2) Every magistrate shall be a presiding officer of a children's court ..."

73. UNICEF, "Children on the Move, A reflection on the challenges of formal placement of non-national unaccompanied minors in South Africa," power point presentation obtained by the author from stakeholder, on file with the author, confirms that "undertones of discrimination [in terms of the attitude of social workers at intake] have been noted in parts of the country. In one location, where children were referred to social workers, discriminatory remarks were cited by the Children including statements 
such as " ... you do not deserve places that were created from South African taxpayers' money” or “ ... you are 17 and will be on the streets in one year so there is no point formally placing you."

74. DSD Guidelines at par 6.1.

75. It should be noted that Sec 150 of the Children's Act provides for the definition of a child in need of care and protection, as follows: "150. (1) A child is in need of care and protection if, the child-

(a) has been abandoned or orphaned and is without any visible means of support;

(b) displays behaviour which cannot be controlled by the parent or care-giver;

(c) lives or works on the streets or begs for a living;

(d) is addicted to a dependence-producing substance and is without any support to obtain treatment for such dependency;

(e) has been exploited or lives in circumstances that expose the child to exploitation;

(f) lives in or is exposed to circumstances which may seriously harm that child's physical, mental or social well-being."

76. DSD Guidelines at par 6.1.

77. This is often the case as the social worker is not aware of how prejudicial it is for a child not to have any enabling documentation in South Africa. Access to school, basic services such as health care, and protection from possible arrest and detention, all result from having the necessary documentation.

78. As background, in 2010 the child was taken by his female relative in Durban to the Department of Home Affairs and was documented at that Refugee Reception Office as an asylum seeker although with a notation on his permit stating "Unaccompany (sic) Minor, referred to Social Development for Legal Custodianship." A copy of permit on file at the UCT RRU. The author submits that the DHA official incorrectly wrote custodianship, rather than guardianship, on the permit.

79. Page 2 of the social worker's report, copy on file at the UCT RRU.

80. In an interview with the UCT RRU attorney, notes on files with the author.

81. Excerpts from email from social worker to UCT RRRU attorney, dated 12 October 2011, copy on file with the author.

82. DSD Guidelines at par 6.1.

83. Children's Act, General Regulations Regarding Children, 2010, CN R261 in GG 33076 of 1 April 2010.

84. Regulation 54 of the 2010 Regulations to the Children's Act 38 of 2005 states that "(1) A Child-

(b) who is not in temporary safe care but is the subject of an investigation as to whether he or she is in need of care or protection; must be brought or caused to be brought before children's court ... by a designated social worker, or in the case of a child referred to in paragraph (b), be brought by his or her parent, guardian or care-giver for a decision on whether the child is need of care and protection by no later than 90 days after-(ii) the commencement of the investigation, in the case of a child contemplated in paragraph (b) ..."

85. Sec 46 of the Children's Act: "A Children's Court may make the following orders: (k) any other order which a children's court may make in terms of any provision of this Act."

86. Sec 23 of the Children's Act: 23.(1) Any person having an interest in the care, well-being or development of a child may apply to the High Court, a divorce court in divorce matters or the children's court for an order granting to the applicant, on such conditions as the court may deem necessary-

(a) contact with the child; or

(b) care of the child.

(2) When considering an application contemplated in subsection (l), the court must take into account-

(a) the best interests of the child;

(b) the relationship between the applicant and the child, and any other relevant

person and the child;

(c) the degree of commitment that the applicant has shown towards the child;

(4) the extent to which the applicant has contributed towards expenses in connection with the birth and maintenance of the child; and

(e) any other fact that should, in the opinion of the court, be taken into account.

It should also be noted that an application for Guardianship may be made by a care-giver to the High Court, as set out in Sec 24 of the Children's Act. In fact, the author is aware of a number of UCT RRU clients that have approached the High Court for such an order, despite the costs involved in same, in order to overcome the documentation challenges presented at the DHA.

87. Mossel Bay is a small seaside town approximately $350 \mathrm{~km}$ from Cape Town, located in the Western Cape Province.

88. Referring of course only to those that have been identified and brought to the attention of legal representatives or other service providers.

89. Sec 53 of the Children's Act refers to an "interested party." See note below.

90. Sec 53 of the Children's Act: (1) Except where otherwise provided in this Act, any person listed in this section may bring a matter which falls within the jurisdiction of a children's court, to a clerk of the children's court for referral to a children's court.

(2) The persons who may approach a court, are:

(a) A child who is affected by or involved in the matter to be adjudicated;

(b) anyone acting in the interest of the child;

(c) anyone acting on behalf of a child who cannot act in his or her own name; 
(4) anyone acting as a member of, or in the interest of, a group or class of children; and $(e)$ anyone acting in the public interest.

91. Sec 23 of the Children's Act: (1) Any person having an interest in the care, well-being or development of a child may apply to the High Court, a divorce court in divorce matters or the children's court for an order granting to the applicant, on such conditions as the court may deem necessary-

(a) contact with the child; or

(b) care of the child.

(2) When considering an application contemplated in subsection (1), the court must take into account-

(a) the best interests of the child;

(b) the relationship between the applicant and the child, and any other relevant

person and the child;

(c) the degree of commitment that the applicant has shown towards the child;

(4) the extent to which the applicant has contributed towards expenses in connection with the birth and maintenance of the child; and

(e) any other fact that should, in the opinion of the court, be taken into account.

92. The Department of Home Affairs is understandably reluctant to provide documentation to an unaccompanied or separated child, in particular as another applicant's dependant, without any proof of relationship between the child and the adult claiming to be a family member.

93. As noted by the author, who has been working at the UCT RRU since 2005.

94. UN High Commissioner for Refugees, "Refugee Children: Guidelines on Protection and Care."

95. Ibid., at 133.

96. UNICEF, "Children on the Move."

97. DSD Guidelines at par 6.2.

98. Art 8 of the UNCRC provides that: "1. States Parties undertake to respect the right of the child to preserve his or her identity, including nationality, name and family relations as recognized by law without unlawful interference. 2 . Where a child is illegally deprived of some or all of the elements of his or her identity, States Parties shall provide appropriate assistance and protection, with a view to re-establishing speedily his or her identity."

99. Ibid.

100. DSD Guidelines at par 6.4.1 and 6.4.2.

101. These children may not be refugees but also cannot be reunited with their family in country of origin or otherwise be returned to their home country.

102. Act 13 of 2002.

103. Immigration Act section 31(2) "Upon application, the Minister, as he or she deems fit. after consultation with the Board, may under terms and conditions determined by him or her ... grant a foreigner or a category of foreigners the rights of permanent residence for a specified or unspecified period when special circumstances exist which justify such a decision."

104. Aids Law Project, Curatrix Report at par 6.4.7 and 6.4.8.

105. For example, the recent Zimbabwean Dispensation Project, in which the Minister of Home Affairs, recognizing the humanitarian nature of the crisis in Zimbabwe, granted four-year work, study and business permits at reduced requirements, in terms of Section 31(2) (b) of the Immigration Act, to large numbers of Zimbabwean migrants of humanitarian concern present in South Africa.

106. Feijen, "The Challenges of Ensuring Protection," 9.

107. See for example, Lawyers for Human Rights, "Home Affairs Prevents Refugees from Applying for Asylum," accessed on 2 February 2012, at http://www.lhr.org.za/news/2012/renegade-department-prevents-refugees-applying-asylum-1, which raises concerns about DHA's apparent policy of exclusion of migrants rather than protection.

Tal Schreier (BA, LLB, JD, LLM) is an Attorney of the Supreme Court of Canada and a senior Refugee Counsellor in the University of Cape Town Refugee Rights Unit. In addition to her general work in the Unit, she conducts regular workshops and seminars aimed at professionals in different fields who interact with Refugees and Asylum Seekers. 
(C) Tal Schreier, 2011. This open-access work is licensed under a Creative Commons Attribution-NonCommercial 4.0 International License, which permits use, reproduction and distribution in any medium for non-commercial purposes, provided the original author(s) are credited and the original publication in Refuge: Canada's Journal on Refugees is cited. 